ROCZNIKI NAUK PRAWNYCH

Tom XXX, numer $3-2020$

DOI: https://doi.org/10.18290/rnp20303-5

WOJCIECH LIS

\title{
ZEZWOLENIE SĄDU OPIEKUŃCZEGO NA UDZIELENIE MAŁOLETNIEMU ŚWIADCZENIA ZDROWOTNEGO
}

\author{
1. ZGODA NA UDZIELENIE ŚWIADCZENIA ZDROWOTNEGO \\ JAKO WYRAZ AUTONOMII DECYZYJNEJ
}

Warunkiem udzielenia świadczenia zdrowotnego ${ }^{1}$ jest zgoda pacjenta ${ }^{2}$. Przyjęte rozwiązanie wynika z podmiotowości pacjenta, mającej swoje źródło w godności człowieka, będącego punktem odniesienia wszelkich działań ze strony władz publicznych, których celem powinno być jego dobro w ujęciu jednostkowym i zbiorowym (art. 30 Konstytucji RP ${ }^{3}$ ). Zasadę tę wzmacniają kolejne postanowienia Konstytucji RP, wśród których należy wskazać przede wszystkim gwarancje zapewniające każdemu nietykalność i wolność

Dr hab. WoJcIEch LIS, prof. KUL - Katedra Prawa Rodzinnego i Praw Rodziny, Instytut Nauk Prawnych, Wydział Prawa, Prawa Kanonicznego i Administracji, Katolicki Uniwersytet Lubelski Jana Pawła II, Al. Racławickie 14, 20-950 Lublin; e-mail: wlis@kul.lublin.pl; ORCID: https://orcid.org/0000-0002-9014-0749

${ }^{1}$ Zgodnie z art. 2 ust. 1 pkt 10 ustawy z dnia 15 kwietnia 2011 r. o działalności leczniczej (tekst jedn. Dz. U. 2018, poz. 2190 z późn. zm.) świadczenie zdrowotne to działanie służące zachowaniu, ratowaniu, przywracaniu lub poprawie zdrowia oraz inne działania medyczne wynikające z procesu leczenia lub przepisów odrębnych regulujących zasady ich wykonywania.

${ }^{2}$ Zgoda pacjenta, wyłączająca bezprawność naruszenia dóbr osobistych, nie jest typowym oświadczaniem woli; jest przejawem woli podobnym do oświadczenia woli, co przemawia za odpowiednim stosowaniem do niej przepisów dotyczących oświadczeń woli oraz czynności prawnych, w szczególności przepisów regulujących skutki złożenia wadliwego oświadczenia woli (art. 82 Kodeksu cywilnego) oraz formę czynności prawnych (art. 73 Kodeksu cywilnego), wyrok Sądu Najwyższego z dnia 11 kwietnia 2006 r., II CSK 191/05, LEX nr 274261. Należy jednak podkreślić, że celem udzielającego zgody pacjenta nie jest wywołanie określonych skutków prawnych, lecz danie wyrazu swej woli zadysponowania sobą w zakresie poddania się interwencji medycznej. W przejawach woli skutek prawny następuje niezależnie od intencji działającego, z kolei w oświadczeniach wola skierowana jest na jego wywołanie; K. MichaŁowsKA, Charakter prawny i znaczenie zgody pacjenta na zabieg medyczny, Warszawa: Difin S.A. 2014, s. 163 i n.

${ }^{3}$ Konstytucja Rzeczypospolitej Polskiej z dnia 2 kwietnia 1997 r., Dz. U. 1997, nr 78, poz. 483 z późn. zm. 
osobistą (art. 41 ust. 1 zd. 1) czy prawo do ochrony prawnej życia prywatnego oraz do decydowania o swoim życiu osobistym (art. 47). Każda interwencja medyczna wiąże się bowiem z wkroczeniem w sferę dóbr i wartości najcenniejszych - życia i zdrowia człowieka, stąd każdy ma samodzielnie decydować o poddaniu się takiej interwencji bądź rezygnacji z takiej możliwości. Prawo do decydowania o samym sobie, w tym do poddania się interwencji medycznej, jest jednym z przejawów autonomii jednostki i swobody dokonywania przez nią samodzielnych wyborów ${ }^{4}$. Podjęcie interwencji medycznej bez zgody pacjenta albo wbrew jego woli powoduje odpowiedzialność cywilną, karną, dyscyplinarną i zawodową. Tym bardziej, że każda interwencja medyczna zawsze wiąże się z ryzykiem niekorzystnych dla pacjenta skutków, z utratą życia włącznie. $Z$ powyższego wynika zatem, że warunkiem podjęcia interwencji medycznej jest zgoda pacjenta, która legitymizuje działania lekarza. Instytucja zgody odnosi się do szerokiego spektrum działań lekarskich - od diagnostyki i badań do leczenia zabiegowego i operacyjnego, w warunkach ambulatoryjnych i szpitalnych ${ }^{5}$. Zgodę taką może wyrazić tylko pacjent pełnoletni i nieubezwłasnowolniony. W przypadku pacjentów małoletnich ${ }^{6}$, wymagających stałej pieczy dorosłych, zgodę na interwencję medyczną podejmują osoby trzecie - przedstawiciel ustawowy, opiekun prawny, opiekun faktyczny, w ostateczności sąd opiekuńczy. Podstawowe zasady udzielania świadczeń zdrowotnych określają przede wszystkim ustawy z dnia 5 grudnia 1996 r. o zawodach lekarza i lekarza dentysty $^{7}$ oraz ustawa $z$ dnia 6 listopada 2008 r. o prawach pacjenta i Rzeczniku Praw Pacjenta ${ }^{8}$. Poza tym oczywiście także szereg innych aktów normatywnych regulujących wykonywanie poszczególnych zawodów medycznych.

\footnotetext{
${ }^{4}$ Wyrok Sądu Najwyższego z dnia 16 maja 2012 r., III CSK 227/11, LEX nr 1211885.

${ }^{5}$ Wyrok Trybunału Konstytucyjnego z dnia 11 października 2011 r., K 16/10, LEX nr 992832.

${ }^{6}$ Pojęcie małoletniości należy rozumieć w sposób przyjęty w wykładni przepisów prawa cywilnego, czyli przez odniesienie do uzyskania pełnoletności. Granica pełnoletności na gruncie przepisów prawa cywilnego została ustalona na poziomie lat 18. Prawodawca dopuszcza tylko jeden wyjątek uzyskania pełnoletności przez osoby poniżej lat 18, odnosząc go do małoletnich, którzy zawarli małżeństwo (art. 10 ustawy z dnia 3 kwietnia 1964 r. Kodeks cywilny, tekst jedn. Dz. U. 2019, poz. 1145 z późn. zm., dalej: KC).

${ }^{7}$ Ustawa z dnia 5 grudnia 1996 r. o zawodach lekarza i lekarza dentysty, tekst jedn. Dz. U. 2019, poz. 537 z późn. zm. (dalej: u.z.1.).

${ }^{8}$ Ustawa z dnia 6 listopada 2008 r. o prawach pacjenta i Rzeczniku Praw Pacjenta, tekst jedn. Dz. U. 2019, poz. 1127 z późn. zm. (dalej: u.pr.pac.).
} 


\section{PRAWO DO WYRAŻENIA ZGODY NA UDZIELENIE MAŁOLETNIEMU ŚWIADCZENIA ZDROWOTNEGO}

$Z$ reguły małoletni pozostaje pod władzą rodzicielską swoich rodziców, którzy są także jego przedstawicielami ustawowymi. Oznacza to, że każdy z rodziców jest podmiotem władzy rodzicielskiej, na którą, stosownie do art. $95 \S 1$ ustawy z dnia 25 lutego 1964 r. Kodeks rodzinny i opiekuńczy, składa się obowiązek i prawo rodziców do wykonywania pieczy nad osobą i majątkiem dziecka oraz do wychowania dziecka9 ${ }^{9}$ Rodzice są obowiązani troszczyć się o fizyczny i duchowy rozwój dziecka (art. $96 \S 1$ KRiO), którego elementem jest niewątpliwie zapewnienie mu opieki zdrowotnej adekwatnie do potrzeb. Co do zasady podejmowanie decyzji dotyczących interwencji medycznych podyktowane jest dobrem dziecka. Z kolei troska o dobro dziecka zdeterminowana jest istnieniem więzi uczuciowych między rodzicami i dzieckiem. Zgodnie z art. $97 \S 1 \mathrm{KRiO}$ „Jeżeli władza rodzicielska przysługuje obojgu rodzicom, każde $\mathrm{z}$ nich jest obowiązane i uprawnione do jej wykonywania". Jeżeli dziecko pozostaje pod władzą rodzicielską obojga rodziców to każde z nich może działać samodzielnie jako jego przedstawiciel ustawowy (art. $98 \S 1 \mathrm{KRiO}$ ).

Należy odróżnić od tego powinność wspólnego rozstrzygania przez rodziców o istotnych sprawach dziecka. Zgodnie bowiem z art. $97 \S 2 \mathrm{KRiO}$ o istotnych sprawach dziecka rodzice rozstrzygają wspólnie; w braku porozumienia między nimi rozstrzyga sąd opiekuńczy. Wynika stąd, że każdego z rodziców, któremu przysługuje władza rodzicielska, łączy z dzieckiem odrębny stosunek rodzinnoprawny, którego treścią jest władza rodzicielska. Każdy z tych stosunków jest samodzielny, z tym że samodzielność ta nie dotyczy istotnych spraw dziecka, o których rodzice zobowiązani są rozstrzygać wspólnie. Nie oznacza to jednak, że działanie podjęte w wykonaniu uzgodnionej decyzji zawsze musi mieć charakter wspólny. Postanowienia art. 97 KRiO nie mogą stanowić podstawy do przyjęcia zasady reprezentacji łącznej dziecka przez rodziców w jego istotnych sprawach ${ }^{10}$. Byłoby to niezwykle trudne do wyegzekwowania $\mathrm{w}$ praktyce, a przez to pozostawałoby $\mathrm{w}$ sprzeczności z dobrem dziecka. $Z$ treści przepisu wynika, że nie chodzi o reprezentację łączną, ale o wspólne rozstrzygnięcie sprawy dziecka, którą kwalifikuje się

\footnotetext{
${ }^{9}$ Ustawa z dnia 25 lutego 1964 r. Kodeks rodzinny i opiekuńczy, tekst jedn. Dz. U. 2019, nr 2086 (dalej: KRiO).

${ }^{10}$ Postanowienie Sądu Najwyższego z dnia 3 czerwca 2011 r., III CSK 259/10, LEX nr 1129120.
} 
jako istotną. Oznacza to, że także $w$ istotnych sprawach wystarcza jednoosobowa reprezentacja dziecka przez któregokolwiek z rodziców.

Jeżeli władza rodzicielska przysługuje tylko jednemu z rodziców, wówczas tylko tego rodzica, któremu ta władza przysługuje, łączy z dzieckiem stosunek rodzinnoprawny, którego treścią jest władza rodzicielska. Samodzielność stosunku rodzinnoprawnego oznacza również samodzielność w rozstrzyganiu o istotnych sprawach dziecka ${ }^{11}$, co modyfikuje zasadę wynikającą z art. $97 \S 2$ KRiO. Przyczyną przysługiwania władzy rodzicielskiej tylko jednemu z rodziców jest śmierć drugiego z nich, brak pełnej zdolności do czynności prawnych, pozbawienie go władzy rodzicielskiej, ograniczenie jej albo zawieszenie (art. $94 \S 1 \mathrm{KRiO}$ ). W razie powierzenia wykonywania władzy rodzicielskiej tylko jednemu z rodziców drugiemu $\mathrm{z}$ nich władza ta przysługuje tylko $\mathrm{w}$ takim zakresie, w jakim zostało to oznaczone przez sąd. Należy podkreślić, że zarówno w przypadku braku porozumienia między rodzicami, którym władza rodzicielska przysługuje w jednakowym zakresie, jak również w przypadku powierzenia władzy rodzicielskiej tylko jednemu z rodziców, pojawia się problem dopuszczalności weryfikacji przez lekarza, czy zgoda udzielona przez rodzica małoletniego pacjenta na udzielenie mu świadczenia zdrowotnego faktycznie pochodzi od osoby uprawnionej. Próba ustalenia podczas wywiadu z rodzicem małoletniego pacjenta przysługującej mu kompetencji decyzyjnej nieuchronnie wiąże się bowiem z ingerencją w sferę życia prywatnego, do czego lekarz nie jest uprawniony.

Nikt bezkarnie nie może ingerować w sferę życia prywatnego drugiego człowieka bez wyraźnej podstawy prawnej. O ile w odniesieniu do przeprowadzenia badania, z uwagi na charakter podejmowanych czynności, problem ów może nie mieć większego znaczenia, o tyle już w przypadku konieczności udzielenia świadczenia zdrowotnego polegającego na wykonaniu zabiegu związanego z ingerencją $\mathrm{w}$ ciało człowieka może wybrzmieć z całą mocą. Wydaje się, że w przypadku powzięcia wątpliwości co do kompetencji decyzyjnej rodzica małoletniego pacjenta lekarz powinien zwrócić się do sądu opiekuńczego o wyrażenie zezwolenia na udzielenie świadczenia zdrowotnego. Należy dodać, że lekarz powinien zwrócić się do sądu opiekuńczego także w sytuacji dążenia rodziców do poddania swego dziecka interwencjom medycznym, które stwarzają dla niego ryzyko niewspółmiernie duże w po-

${ }^{11}$ H. HAAK, Komentarz do art. 94, punkt 1, [w:] Pokrewieństwo i powinowactwo (pochodzenie dziecka, stosunki między rodzicami a dziećmi, przysposobienie). Komentarz do art. $61^{7}$ 127 KRO oraz zwiazanych z nimi regulacji K.P.C. (art. 453-458, 579-589), H. HAAK, A. HAAK-TRZUSKAwSKA, Warszawa: C.H. Beck 2019. 
równaniu do przewidywanych korzyści. Nie zawsze bowiem samo powołanie się na cel podejmowanych działań medycznych lub zgoda wyrażona przez rodziców oznaczają konieczność interwencji medycznej. W przypadku wątpliwości co do istnienia wskazania medycznego dla podjęcia interwencji mogących wpływać na kondycję zdrowotną małoletniego pacjenta lekarz ma obowiązek zawiadomić o tym sąd opiekuńczy w celu zdecydowania przez niego o podjęciu stosownych $\mathrm{w}$ takiej sytuacji czynności, m.in. prowadzących do ograniczenia władzy rodzicielskiej.

Kategoria istotnych spraw dziecka ma charakter niedookreślony, zindywidualizowany, odniesiony wyłącznie do konkretnego przypadku. W związku z tym nie jest możliwe sformułowanie zamkniętego katalogu takich spraw. Nie budzi jednak żadnych wątpliwości, że sprawy takie muszą mieć charakter doniosły, ważny z punktu widzenia sprawowania pieczy nad dzieckiem. Do katalogu istotnych spraw dziecka zalicza się niewątpliwie troskę o stan jego zdrowia. Oznacza to, że prawo do wyrażenia zgody na udzielenie małoletniemu świadczenia zdrowotnego jest powiązane $\mathrm{z}$ władzą rodzicielską i przysługuje osobie, pod władzą której pozostaje. W przypadkach świadczeń zdrowotnych uznanych za istotne sprawy dziecka lekarz powinien uzyskać zgodę obojga rodziców. Jednakże określenie, które świadczenia zdrowotne w konkretnym przypadku mają taki charakter, jest niezwykle problematyczne. W doktrynie przyjmuje się elastyczną koncepcję wykładni pojęcia istotnych spraw dziecka, która nakazuje lekarzowi odwoływać się do kryteriów subiektywnych (oceny wnioskodawcy). W takim to ujęciu już sam konflikt ujawniający się w przeciwstawnych sobie decyzjach rodziców decydowałby o uznaniu sprawy za istotną. Rozwiązanie takie podyktowane jest dobrem dziecka, w którego interesie leży rozwiązanie konfliktu istniejącego między rodzicami odpowiedzialnymi za stan jego zdrowia ${ }^{12}$. Przy czym chodzi oczywiście o konflikt, którego przedmiotem są wyłącznie sprawy dziecka, nie sprawy jego rodziców. Stosownie do art. 582 ustawy z dnia 17 listopada 1964 r. Kodeks postępowania cywilnego ${ }^{13}$ w przypadku braku porozumienia między rodzicami dziecka co do sposobu rozstrzygnięcia o jego istotnych sprawach rozstrzyga o nich sąd opiekuńczy, po uprzednim umożliwieniu rodzicom złożenia oświadczeń, chyba że wysłuchanie ich byłoby połączone

\footnotetext{
${ }^{12}$ W. STOJANOWSKA, Rozstrzyganie przez sad na podstawie art. 24 i 97 \$ 2 K.R.O o istotnych sprawach rodziny $w$ braku porozumienia między matzonkami lub rodzicami, „Nowe Prawo" 1985, nr 7-8, s. 82-83.

${ }^{13}$ Ustawa z dnia 17 listopada 1964 r. Kodeks postępowania cywilnego, tekst jedn. Dz. U. 2019, poz. 1460 z późn. zm. (dalej: KPC).
} 
z nadmiernymi trudnościami. Sprawy o rozstrzyganie o istotnych sprawach dziecka rozpoznawane są $\mathrm{w}$ trybie nieprocesowym $\mathrm{w}$ oparciu na przepisach art. $568-578^{2}$ KPC.

Należy podkreślić, że $\mathrm{w}$ takim przypadku przedmiotem rozstrzygnięcia sądu opiekuńczego nie jest udzielenie zezwolenia na wykonanie konkretnego świadczenia zdrowotnego, co do którego rodzice małoletniego pacjenta nie zdołali się porozumieć. Orzeczenie sądu opiekuńczego nie zastępuje oświadczenia o zgodzie na wykonanie czynności medycznej, usuwa jedynie brak porozumienia, uniemożliwiający złożenie przez jednego z rodziców prawnie doniosłego oświadczenia w przedmiocie zgody. W konsekwencji rodzic, którego stanowisko $\mathrm{w}$ przedmiocie interwencji medycznej zostało podzielone, dysponując stosownym postanowieniem sądu opiekuńczego, może wyrazić zgodę na udzielenie dziecku świadczenia zdrowotnego albo odmówić wykonania takiego świadczenia ${ }^{14}$.

W przypadku małoletnich, którzy nie pozostają pod władzą rodzicielską, ustanawia się dla nich opiekuna prawnego (art. $94 \S 3 \mathrm{KRiO}$ ). Do sprawowania opieki stosuje się odpowiednio przepisy o władzy rodzicielskiej (art. 155 $\S 2 \mathrm{KRiO}$ ). Jeżeli przedstawicielem ustawowym małoletniego jest opiekun prawny wyznaczony przez sąd opiekuńczy, to stosownie do art. $156 \mathrm{KRiO}$, powinien on uzyskać zezwolenie sądu opiekuńczego we wszelkich ważniejszych sprawach, które dotyczą małoletniego. Oznacza to, że pomimo tego, iż opiekun prawny traktowany jest jak rodzic, to jednak nie przysługuje mu pełna swoboda decyzyjna w zakresie spraw swego podopiecznego. W zakresie czynności leczniczych podejmowanych wobec małoletniego pacjenta swoboda decyzyjna opiekuna prawnego ogranicza się zatem wyłącznie do badania diagnostycznego, wszelkie inne czynności lecznicze uzależnione są od zezwolenia sądu opiekuńczego.

Zgodę na udzielanie świadczeń zdrowotnych może skutecznie wyrazić także opiekun faktyczny, czyli osoba sprawująca, bez obowiązku ustawowego, stałą opiekę nad pacjentem, który ze względu na wiek, stan zdrowia albo stan psychiczny opieki takiej wymaga (art. 3 ust. 1 pkt 1 u.pr.pac.). Źródłem umocowania opiekuna faktycznego jest zatem rzeczywiste, stałe sprawowanie opieki nad małoletnim. $Z$ reguły opiekunem faktycznym małoletniego będzie osoba bliska (krewny do drugiego stopnia lub powinowaty do drugiego stopnia w linii prostej, przedstawiciel ustawowy czy osoba przez

\footnotetext{
${ }^{14}$ B. JANISZEWSKA, Zgoda na udzielenie świadczenia zdrowotnego. Ujęcie wewnątrzsystemowe, Warszawa: C.H. Beck 2013, s. 529.
} 
niego wskazana, zgodnie z art. 3 ust. 1 pkt 2 u.pr.pac.), co jednak nie oznacza, że każda osoba bliska, tylko z tego faktu, automatycznie będzie posiadała status opiekuna faktycznego. Tymczasem lekarze niespecjalnie przywiązują wagę do tego, czy osoba towarzysząca małoletniemu rzeczywiście posiada status opiekuna faktycznego. W konsekwencji może przeprowadzić badanie na podstawie zgody udzielonej przez osobę do tego nieuprawnioną. Przy okazji należy podkreślić, że - co prawda - opiekun faktyczny może skutecznie wyrażać zgodę na udzielanie małoletniemu świadczeń zdrowotnych, ale ich zakres objętych jego zgodą jest dużo węższy od zakresu świadczeń zdrowotnych objętych zgodą przedstawiciela ustawowego czy nawet opiekuna prawnego; dotyczy jedynie zgody na przeprowadzenie badania diagnostycznego. Przez badanie takie należy rozumieć podstawowe czynności lekarskie polegające na badaniu fizykalnym, które pozwalają określić stan zdrowia pacjenta. Inaczej mówiąc, są to podejmowane dla dobra pacjenta rutynowe, nieinwazyjne, nienaruszające integralności fizycznej pacjenta, niestwarzające ryzyka dla zdrowia i życia czynności medyczne. Zakres zgody udzielonej przez opiekuna faktycznego ogranicza się zatem wyłącznie do czynności medycznych mających na celu ocenę stanu zdrowia i to z zastosowaniem metod diagnostyki niestwarzających ryzyka dla pacjenta ${ }^{15}$. Pojawia się jednak wątpliwość natury praktycznej, mianowicie z uwagi na charakter niektórych badań fizykalnych, m.in. ginekologicznych czy dermatologicznych, zgoda opiekuna faktycznego może prowadzić do bezprawnego naruszenia dóbr osobistych małoletniego, z kolei lekarza przeprowadzającego badanie narazić na odpowiedzialność z powodu bezprawnej interwencji medycznej ${ }^{16}$.

$\mathrm{Na}$ podstawie zgody wyrażonej przez opiekuna faktycznego małoletniego pacjenta lekarz może podjąć interwencję medyczną jedynie w celu przeprowadzenia wstępnej oceny i określenia potrzeby udzielenia świadczenia zdrowotnego, zwłaszcza że opiekun faktyczny nie jest uprawniony do wyrażenia zgody na poszerzoną diagnostykę i leczenie stwarzające podwyższone ryzyko dla pacjenta. Oznacza to, że w pierwszej kolejności lekarz powinien podjąć próbę skontaktowania się z przedstawicielem ustawowym w celu zawiadomienia go o sytuacji zdrowotnej małoletniego pacjenta, a kiedy próba ta okaże się nieskuteczna albo w przypadku braku przedstawiciela ustawowego - zwrócić się do sądu opiekuńczego o zezwolenie na przeprowadzenie

\footnotetext{
${ }^{15} \mathrm{~W}$. LIS, Zgoda pacjenta na czynność medyczna $w$ polskim porzadku prawnym, „Zeszyty Naukowe KUL" 2018, nr 3, s. 42.

${ }^{16}$ M. SADOWSKA, Zapobieganie błędom medycznym w praktyce, Warszawa: Wolters Kluwer 2019, s. 121.
} 
wymaganej w okolicznościach danego przypadku diagnostyki i udzielenie odpowiednich do poczynionych ustaleń świadczeń zdrowotnych ${ }^{17}$.

\section{PRZESŁANKI WYRAŻENIA ZGODY NA UDZIELENIE ŚWIADCZENIA ZDROWOTNEGO}

By zgoda na udzielenie świadczenia zdrowotnego była ważna i skuteczna osoba ją udzielająca - odpowiednio pacjent pełnoletni i nieubezwłasnowolniony, przedstawiciel ustawowy małoletniego pacjenta, opiekun prawny albo opiekun faktyczny - musi zostać poinformowana przez lekarza o proponowanym leczeniu, jego przebiegu i oczekiwanych skutkach, możliwych powikłaniach i alternatywnych możliwościach, jeżeli istnieją. $Z$ uwagi na wynikającą z godności człowieka autonomię decyzją zgoda na udzielenie świadczenia zdrowotnego ma być zgodą uświadomioną poinformowanego pacjenta.

Przyjmuje się, że pacjent (bądź osoba działająca w jego imieniu) działa świadomie, kiedy posiada wiedzę o tym, jakiej interwencji medycznej powinien się poddać, dlaczego i jakie wiążą się z tym konsekwencje; nie może bowiem skutecznie udzielić zgody na coś, o czym nic nie wie. Źródłem wiedzy i warunkiem skutecznego wyrażenia zgody jest informacja. Pacjent ma bowiem prawo do informacji o stanie swego zdrowia (art. 9 ust. 1 u.pr.pac.). „Lekarz ma obowiązek udzielać pacjentowi lub jego przedstawicielowi ustawowemu przystępnej informacji o jego stanie zdrowia, rozpoznaniu, proponowanych oraz możliwych metodach diagnostycznych, leczniczych dających się przewidzieć następstwach ich zastosowania albo zaniechania, wynikach leczenia oraz rokowaniu" (art. 31 ust. 1 u.z.1.). Obowiązek informacyjny dotyczy także małoletnich pacjentów, którzy ukończyli 16 lat. Lekarz przekazuje im informacje $\mathrm{w}$ zakresie i formie potrzebnej do prawidłowego przebiegu procesu diagnostycznego lub terapeutycznego oraz wysłuchuje ich zdania. Oznacza to, że informacje przekazywane małoletnim pacjentom różnią się od informacji przekazywanych dorosłym pacjentom, niemiej jednak muszą one być na tyle szczegółowe, by małoletni pacjenci mogli na ich podstawie samodzielnie ocenić stan swego zdrowia i konieczność przeprowadzenia interwencji medycznej. Innymi słowy, informacje te pozwalają zaangażować małoletnich pacjentów w proces diagnostyczny lub terapeutyczny oraz pozyskać ich zrozumienie względem podejmowanych czynności leczniczych.

\footnotetext{
17 Tamże.
} 
Jeżeli małoletni pacjent nie ukończył 16 lat, to lekarz udziela informacji wyłącznie osobie bliskiej takiemu pacjentowi w rozumieniu art. 3 ust. 1 pkt 2 u.pr.pac.

Zakres obowiązku informacyjnego jest ujęty szeroko, dotyczy wszelkich działań lekarza, nie tylko zabiegów inwazyjnych. Pacjent musi zostać poinformowany o stanie swego zdrowia, rokowaniach, metodach leczenia oraz ryzyku, jakie się z nimi wiążą. Zakres przekazywanych informacji powinien być zindywidualizowany, dostosowany do poziomu intelektualnego i możliwości percepcyjnych oraz stanu emocjonalnego pacjenta, który będzie różny, w zależności od tego, czy chodzi o interwencję medyczną mającą na celu ratowanie życia, czy tylko polepszenie stanu zdrowia ${ }^{18}$. Informacja taka powinna zostać przekazana przed przystąpieniem przez lekarza do udzielania świadczenia zdrowotnego (zgoda udzielona w trakcie udzielania świadczenia zdrowotnego albo dopiero po jego udzieleniu nie legitymizuje zachowania lekarza), w sposób wyczerpujący i zrozumiały dla odbiorcy. Miarodajna, legalizująca działanie lekarza zgoda pacjenta na wykonanie zabiegu leczniczego to taka zgoda, która stanowi wyraz jego własnej, świadomej, czyli nieobciążonej wadą błędu czy przymusu, decyzj1 ${ }^{19}$. Oznacza to, że zakres obowiązku informacyjnego nie zależy od tego, co lekarz sądzi na temat tego, ile pacjent może i powinien wiedzieć, lecz zależy od tego, co rozsądna osoba będąca $\mathrm{w}$ sytuacji pacjenta obiektywnie potrzebuje usłyszeć od lekarza, by podjąć „poinformowaną” decyzję wobec proponowanej interwencji medycznej ${ }^{20}$. Dzięki temu pacjent będzie mógł podjąć decyzje oddziałujące na stan jego zdrowia w sposób świadomy, wolny od domysłów i przypuszczeń, uwzględniając konsekwencje poddania się albo niepoddania się interwencji medycznej. Brak informacji będących podstawą świadomego wyrażenia zgody wyklucza możliwość podjęcia względem pacjenta jakichkolwiek czynności leczniczych. Pacjent, który świadomie wyraża zgodę na udzielenie mu świadczenia zdrowotnego, przejmuje na siebie związane z tym ryzyko, obejmujące jego bezpośrednie, typowe, dające się przewidzieć zwykłe skutki. Żaden przepis nie określa tego, czy pacjent ma otrzymać informację w formie ustnej czy pisemnej. Przyjmuje się, że informacja zapewniająca

\footnotetext{
${ }^{18}$ W. LIS, Btędy zwiazane z wyrażaniem zgody na udzielenie świadczenia zdrowotnego, „Zeszyty Naukowe KUL" 2018, nr 4, s. 398.

${ }^{19}$ Postanowienie Sądu Najwyższego z dnia 10 kwietnia 2015 r., III KK 14/15, LEX nr 1712821.

${ }^{20}$ Wyrok Sądu Apelacyjnego w Poznaniu z dnia 29 września 2005 r., I ACa 236/05, LEX nr 175206
} 
pacjentowi warunki do wyrażenia zgody uświadomionej nie wymaga formy pisemnej $^{21}$. Należy dodać, że pacjent nie obejmuje treścią zgody szkody wynikłej z niedbalstwa lub innego zawinionego działania lekarza spowodowanego nieudolnością, niezręcznością, nieuwagą, brakiem wiedzy, kwalifikacji czy doświadczenia.

Obowiązek udzielenia pacjentowi informacji obciąża lekarza, który wywodzi z tego skutki prawne; na nim spoczywa dowód wykonania tego obowiązku. Dowodem tego mogą być odpowiednie zapisy w historii choroby wraz $\mathrm{z}$ podpisem pacjenta, wręczone $\mathrm{mu}$ informacje pisemne, zeznania świadków, w tym personelu medycznego. Lekarz musi udowodnić, że informacje o ryzyku i skutkach zabiegów leczniczych lub badań diagnostycznych stanowiły podstawę zgody pacjenta na ich dokonanie lub odmowę zgody ${ }^{22}$. W tym kontekście należy podkreślić, że nie można utożsamiać formularza zgody, nawet takiego, który został właściwe przygotowany i zawiera zindywidualizowane treści, ani ze spełnieniem obowiązku informacyjnego, ani z odebraniem zgody. Nie do przyjęcia jest zatem oparcie działań lekarza wyłącznie na wręczeniu pacjentowi formularza zgody, nie może on zastępować obowiązku przekazania pacjentowi niezbędnych informacji, ani tym bardziej udzielenia jej w sposób przystępny i wyczerpujący ${ }^{23}$. Formularze zgody pełnią wyłącznie funkcję pomocniczą, mogą przybliżyć pacjentowi informacje o konkretnej czynności leczniczej, ale nie mogą być traktowane jako wypełnienie obowiązku informacyjnego ${ }^{24}$. Zgoda pacjenta musi być zgodą „objaśnioną”, „poinformowaną”, akceptującą zrozumiałe przezeń ryzyko dokonania zabiegu i przyjęcie na siebie tego ryzyka. Dopiero taka zgoda pacjenta wyłącza bezprawność interwencji medycznej. Samo uzyskanie formalnej zgody pacjenta bez poinformowania go o dostępnych metodach, ryzyku i następstwach interwencji medycznej powoduje, że jest to zgoda „nieobjaśniona", udzielona w oparciu na niepełnych, nierzetelnych czy niezrozumiałych informacjach i jako taka wadliwa, wskutek czego lekarz działa bez zgody i naraża się na odpowiedzialność cywilną za szkodę wyrządzoną pacjentowi, nawet wówczas, kiedy postępuje zgodnie z zasadami sztuki lekarskiej ${ }^{25}$. Na marginesie tylko należy dodać, że sformułowanie „sztuka lekarska” jest nie-

\footnotetext{
${ }^{21}$ Wyrok Sądu Apelacyjnego w Warszawie z dnia 5 lutego 2016 r., I ACa 609/15, LEX nr 2050471

${ }^{22}$ Wyrok Sądu Najwyższego z dnia 17 grudnia 2004 r., II CK 303/04, LEX nr 157493.

${ }^{23}$ W. Lis, Błędy związane $z$ wyrazaniem zgody, s. 402.

${ }^{24}$ M. SADOWSKA, Zapobieganie błędom medycznym w praktyce, s. 132.

${ }^{25}$ Wyrok Sądu Apelacyjnego w Szczecinie z dnia 2 sierpnia 2012 r., I ACa 443/12, LEX nr 1237851.
} 
porozumieniem powielanym jednak w doktrynie i w orzecznictwie. Działalność lekarza nie jest i nie może być traktowana jak sztuka, gdyż ta $\mathrm{z}$ istoty rzeczy ma charakter działania przypadkowego, opartego na jego intuicji czy kreatywności, odznacza się dowolnością działania. Tymczasem od lekarza oczekuje się i zarazem wymaga działania profesjonalnego, zgodnego z aktualną wiedzą medyczną opartą na wynikach badań naukowych i do tego utrzymanego w granicach prawa.

Zgoda pacjenta ma charakter konkretny, co oznacza, że odnosi się do ściśle określonej czynności, nie obejmuje swoim zakresem kolejnych czynności leczniczych, które powinny być objęte odrębnymi zgodami ${ }^{26}$. Oznacza to, że lekarz musi uzyskać zgodę pacjenta na wszelkie działania, w tym również te, które mają charakter diagnostyczny. Zgoda na przeprowadzenie badania diagnostycznego lub udzielenie innych świadczeń zdrowotnych może zostać wyrażona ustnie albo przez takie zachowanie się pacjenta, które w sposób niebudzący wątpliwości wskazuje na wolę poddania się czynnościom proponowanym przez lekarza albo brak takiej woli (art. 32 ust. 7 u.z.l. w zw. $\mathrm{z}$ art. 17 ust. 4 u.pr.pac.).

Brak sprzeciwu pacjenta na udzielenie świadczenia zdrowotnego nie oznacza jego zgody, gdyż nie ujawnia jego woli w sposób dostateczny. Przyjęcie zgody dorozumianej (milczącej) może mieć zastosowanie jedynie w sytuacji, kiedy chodzi o czynności rutynowe, które nie wiążą się z ryzykiem dla pacjenta albo ryzyko to jest niewielkie. Tego rodzaju zgoda (z uwagi na komfort pracy lekarza oraz czas niezbędny na świadczenia zdrowotne) jest wystarczająca w przypadku większości świadczeń zdrowotnych, np. badania fizykalnego pacjenta czy prostych badań diagnostycznych, np. pobrania krwi do badań laboratoryjnych. Co więcej, już samo przyjście do lekarza lub zgłoszenie się na określone badania oznacza zgodę na poddanie się takim nieskomplikowanym działaniom. W sytuacji, kiedy interwencja medyczna wiąże się z podwyższonym ryzykiem, prawodawca wymaga jednak zgody pisemnej ${ }^{27}$. Zgodnie z art. 34 ust. 1 u.z.1. „Lekarz może wykonać zabieg operacyjny albo zastosować metodę leczenia lub diagnostyki stwarzającą podwyższone ryzyko dla pacjenta po uzyskaniu jego pisemnej zgody”. Wydaje się, że ocenę, czy dana interwencja medyczna stwarza dla pacjenta podwyższone ryzyko, należy oceniać uwzględniając okoliczności danego przypadku, gdyż trudno wskazać jakieś kryteria uniwersalne, odnoszące się do wszystkich

\footnotetext{
${ }^{26}$ Szerzej: M. NeSTEROwicz, Glosa do wyroku Sąu Apelacyjnego w Warszawie z dnia 11 marca 2008 r., I ACa 846/07, „Przegląd Sądowy” 2009, nr 11-12, s. 223.

${ }^{27}$ W. Lis, Zgoda pacjenta na czynność medyczna, s. 48.
} 
pacjentów znajdujących się w podobnej sytuacji. Inne konsekwencje będzie miała interwencja medyczna dla pacjenta zdrowego, zupełnie inne dla pacjenta będącego w złym stanie zdrowia. I o ile w pierwszym przypadku z udzieleniem świadczenia zdrowotnego nie będzie wiązało się dla pacjenta ryzyko, o tyle w drugim przypadku ocena będzie odmienna. Oznacza to, że lekarz udzielający świadczenia zdrowotnego musi dokonywać oceny poziomu ryzyka w odniesieniu do każdego pacjenta indywidualnie ${ }^{28}$. Wynika stąd, że różne są zasady udzielania zgody na badania lekarskie, inne na czynności lecznicze, a zwłaszcza na operacje czy metody leczenia lub diagnostyki stwarzające dla pacjenta podwyższone ryzyko.

\section{WYJĄTEK TERAPEUTYCZNY}

Lekarz jest związany zgodą pacjenta, która określa granice interwencji medycznej. Działanie bez zgody pacjenta albo przekroczenie granic udzielonej zgody stanowi przestępstwo stypizowane w art. $192 \S 1$ ustawy z dnia 6 czerwca 1997 r. Kodeks karny, zgodnie z którym „Kto wykonuje zabieg leczniczy bez zgody pacjenta, podlega grzywnie, karze ograniczenia wolności albo pozbawienia wolności do lat 2 "29. Wynika stąd, że brak zgody pacjenta na zabieg leczniczy jest dla lekarza wiążący i delegalizuje jego działania. Należy dodać, że przepis ów umieszczono w rozdziale zatytułowanym „Przestępstwa przeciwko wolności”, co wskazuje na to, że prawodawca uznał popełnienie stypizowanego $\mathrm{w}$ nim czynu za działanie naruszające prawo człowieka do samostanowienia. Zdarza się jednak, że zakres działań podjętych na podstawie zgody pacjenta $\mathrm{w}$ trakcie ich wykonywania zostaje poszerzony o takie, które przekraczają zakres udzielonej zgody. Sytuację taką, określaną mianem wyjątku terapeutycznego, przewiduje art. 35 u.z.l., zgodnie z którym, jeżeli w trakcie wykonywania zabiegu operacyjnego albo stosowania metody leczniczej lub diagnostycznej wystąpią okoliczności, których nieuwzględnienie groziłoby pacjentowi niebezpieczeństwem utraty życia, ciężkim uszkodzeniem ciała lub ciężkim rozstrojem zdrowia, a nie ma możliwości niezwłocznego uzyskania zgody pacjenta lub jego przedstawiciela ustawowego, lekarz ma prawo, bez uzyskania tej zgody, zmienić zakres zabiegu bądź metody leczenia lub diagnostyki w sposób umożliwiający uwzględ-

\footnotetext{
${ }^{28}$ Ł. CABAN, M. URBAŃSKA, Komentarz do art. 34, punkt 1, [w:] Ustawa o zawodach lekarza i lekarza dentysty. Komentarz, red. M. Kopeć, Warszawa: LEX 2016.

${ }^{29}$ Ustawa z dnia 6 czerwca 1997 r. Kodeks karny, tekst jedn. Dz. U. 2019, poz. 1950 z późn. zm.
} 
nienie tych okoliczności. W takim przypadku lekarz ma obowiązek, o ile to możliwe, zasięgnąć opinii drugiego lekarza, w miarę możliwości tej samej specjalności. O okolicznościach, uzasadniających przekroczenie zgody pacjenta, lekarz zobowiązany jest dokonać odpowiedniej adnotacji w dokumentacji medycznej oraz niezwłocznie poinformować o tym pacjenta, przedstawiciela ustawowego, opiekuna prawnego lub opiekuna faktycznego albo sąd opiekuńczy.

Przyjęte rozwiązanie zostało stworzone na potrzeby praktyki lekarskiej, z której jasno wynikało, że w niektórych przypadkach lekarz może postawić trafną diagnozę dopiero w trakcie wykonywania zabiegu leczniczego. Wyjątek terapeutyczny znajduje zastosowanie wtedy, kiedy zmiana zakresu zabiegu leczniczego była niemożliwa do przewidzenia, a konieczność jej dokonania wynikła dopiero w trakcie udzielania świadczenia zdrowotnego na skutek ujawnienia się okoliczności, o których uprzednio lekarz nie wiedział ${ }^{30}$, i przy dołożeniu należytej staranności, na podstawie dokonanego rozpoznania, potwierdzonego badaniami, nie mógł był wiedzieć. Przepis art. 35 u.z.l. łączy się z naczelną zasadą ratowania życia lub zdrowia ludzkiego w stanach nagłych, o których mowa w treści art. 30 u.z.l. Tego rodzaju sytuacja ma miejsce właśnie w przypadku ujawnienia się / zaistnienia okoliczności, których nieuwzględnienie groziłoby pacjentowi niebezpieczeństwem utraty życia, ciężkim uszkodzeniem ciała lub ciężkim rozstrojem zdrowia oraz $\mathrm{w}$ innych przypadkach niecierpiących zwłoki, a nie ma możliwości niezwłocznego uzyskania zgody pacjenta lub jego przedstawiciela ustawowego, z uwagi na to, że wystąpiły jako okoliczności towarzyszące podstawowemu zakresowi wykonywanych na pacjencie czynności leczniczych.

\section{PODMIOTY UPRAWNIONE DO WYRAŻENIA ZGODY NA UDZIELENIE MAŁOLETNIEMU ŚWIADCZENIA ZDROWOTNEGO}

Zasadą jest, że lekarz może przeprowadzić badanie lub udzielić innych świadczeń zdrowotnych po wyrażeniu zgody przez pacjenta (art. 32 ust. 1 u.z.l.). Zgodę na udzielenie świadczenia zdrowotnego może wyrazić zatem tylko pacjent, który na podstawie udzielonych mu informacji samodzielnie podejmuje decyzję co do poddania się określonym czynnościom leczniczym bądź odmawia poddania się im. W przypadku małoletnich pacjentów na

${ }^{30}$ U. DrozdowsKa, W. WoJTAL, Zgoda i informowanie pacjenta, Warszawa: Eskulap 2010, s. 99. 
przeprowadzenie badania lub udzielenie innych świadczeń zdrowotnych wymagana jest zgoda zastępcza jego przedstawiciela ustawowego, a kiedy pacjent nie ma przedstawiciela ustawowego lub porozumienie się z nim jest niemożliwe - zezwolenie sądu opiekuńczego (art. 32 ust. 2 u.z.l. w zw. z art. 17 ust. 2 zd. 1 u.pr.pac.). Podmiot ów może wyrazić zgodę na udzielenie wszystkich rodzajów świadczeń zdrowotnych, czyli badań lekarskich, prostych czynności diagnostycznych lub zabiegów oraz operacji i metod leczenia lub diagnostyki stwarzających podwyższone ryzyko dla małoletniego pacjenta. Jeżeli małoletni pacjent nie ma przedstawiciela ustawowego ani opiekuna faktycznego albo porozumienie się z tymi osobami jest niemożliwe, lekarz po przeprowadzeniu badania (które nie może jednak stanowić ryzyka dla zdrowia lub życia) może przystąpić do udzielania dalszych świadczeń zdrowotnych dopiero po uzyskaniu zgody sądu opiekuńczego, chyba że co innego wynika z przepisów ustawy (art. 32 ust. 8 u.z.l.) albo zachodzi stan wyższej konieczności (art. 34 ust. 7 u.z.l.). Brak możliwości porozumienia się z przedstawicielem ustawowym albo opiekunem faktycznym może wynikać z braku zainteresowania się małoletnim, porzucenia go, rozkładu więzi rodzinnych, mimo utrzymanej formalnie władzy rodzicielskiej, faktycznej nieobecności z powodu wyjazdu za granicę, przebywania w podmiocie leczniczym, placówce leczenia uzależnień, zakładzie karnym, pozostawania w ciągu alkoholowym lub pod wpływem działania innych środków odurzających bądź niezdolności do wyrażenia zgody. W takich przypadkach zgodę przedstawiciela ustawowego zastępuje zezwolenie sądu opiekuńczego.

Sytuacja małoletnich w kontekście zgody na udzielanie świadczeń zdrowotnych jest jednak zróżnicowana. Kryterium różnicującym uprawnienia małoletnich jest cenzus wiekowy - ukończenie 16 roku życia. W przypadku małoletnich pacjentów, którzy nie ukończyli 16 roku życia, zgodę na podjęcie względem nich interwencji medycznej wyraża przedstawiciel ustawowy albo opiekun faktyczny (zgoda zastępcza). Małoletni przed ukończeniem 16 roku życia nie jest bowiem uprawniony ani do skutecznego wyrażenia zgody, ani do skutecznego wyrażenia sprzeciwu wobec podjęcia względem niego czynności medycznej. Jednakże nawet małoletni pacjent, który nie ukończył 16 roku życia, przed wyrażeniem lub odmową wyrażenia zgody na poddanie go interwencji medycznej przez podmioty do tego uprawnione, ma prawo do przedstawienia własnego stanowiska odnośnie do dotyczących go działań w ramach instytucji wysłuchania przewidzianej w art. $95 \S 4$ KRiO. Stosownie do jego treści „Rodzice przed powzięciem decyzji w ważniejszych sprawach dotyczących osoby lub majątku dziecka powinni je wysłuchać, jeżeli 
rozwój umysłowy, stan zdrowia i stopień dojrzałości dziecka na to pozwala, oraz uwzględnić w miarę możliwości jego rozsądne życzenia". Wysłuchanie małoletniego zapewnia mu możliwość oddziaływania na podmioty decydujące o poddaniu go interwencji medycznej, pewien nieznaczny wpływ na podejmowane względem niego decyzje medyczne. Co więcej, małoletni pacjent ma prawo do wyrażenia swojego zdania, przedstawienia uwag, sugestii czy wątpliwości związanych z procesem diagnostycznym i terapeutycznym oraz do uzyskania informacji dotyczących stanu swego zdrowia. Tymczasem notorycznie pomija się go jako uczestnika działania, którego faktycznie jest podmiotem, ograniczając się jedynie do przeprowadzenia wywiadu z rodzicem albo opiekunem faktycznym. To nie wzbudza zaufania małoletniego do podejmowanych działań, naraża go na stres i narusza obowiązujące prawo (art. 31 ust. 7 u.z.l. w zw. z art. 9 ust. 7 u.pr.pac.). Należy jednak wyraźnie podkreślić, że wysłuchanie dziecka nie oznacza, by z wyrażonym przez niego zdaniem wiązać jakiekolwiek bezpośrednie skutki prawne.

Z kolei małoletni, który ukończył 16 rok życia, ma prawo do współdecydowania o podjęciu względem niego czynności leczniczych. Przyjmuje się, że z chwilą ukończenia 16 roku życia małoletni jest prawnie kompetentny do wyrażenia zgody. U podstaw takiego rozwiązania legło przekonanie, że poziom rozwoju osobistego oraz emocjonalnej i intelektualnej dojrzałości, które człowiek osiąga w wieku 16 lat, uzasadnia przydanie mu uprawnienia do doniosłego jurydycznie wyrażenia woli w ramach współdecydowania o udzieleniu świadczenia zdrowotnego ${ }^{31}$. Stosownie zatem do treści art. 32 ust. 5 u.z.l., jeżeli pacjent ukończył 16 lat, do udzielenia świadczenia zdrowotnego wymagana jest także jego zgoda, określana mianem zgody podwójnej (kumulatywnej, równoległej, towarzyszącej). Rozwiązanie to znajduje potwierdzenie $\mathrm{w}$ art. 17 ust. 1 u.pr.pac., zgodnie z którym „Pacjent, w tym małoletni, który ukończył 16 lat, ma prawo do wyrażenia zgody na przeprowadzenie badania lub udzielenie innych świadczeń zdrowotnych". W takim przypadku konieczne jest uzyskanie zgody podwójnej - pacjenta i jego przedstawiciela ustawowego albo zezwolenia sądu opiekuńczego. Zgoda podwójna stanowi przejaw uznania autonomii decyzyjnej małoletniego pacjenta, jednakże nie na tyle jeszcze samodzielnego decyzyjnie, by wyrazić ją i w konsekwencji poddać się interwencji medycznej bez udziału osób trzecich.

Przyjęte rozwiązanie, uzależniające konieczność uzyskania zgody małoletniego pacjenta na interwencję medyczną od cenzusu wieku, zapewnia równe

${ }^{31}$ B. JANISZEWSKA, Zgoda na udzielenie świadczenia zdrowotnego, s. 524. 
traktowanie pacjentów, którzy ukończyli 16 rok życia. Jeżeliby uzależnić wymaganie uzyskania zgody małoletniego pacjenta od poziomu jego rozwoju osobistego oraz emocjonalnej i intelektualnej dojrzałości to należałoby wiązać to z koniecznością stworzenia instytucjonalnej kontroli tego poziomu w każdym indywidualnym przypadku. Oznaczałoby to z kolei konieczność zapewnienia profesjonalnej obsługi w każdym niemal zakładzie opieki zdrowotnej. W konsekwencji opóźniałoby także udzielenie pomocy medycznej. Inna możliwość, jaką byłoby pozostawienie decyzji w kwestii rozeznania małoletniego pacjenta swobodnej ocenie personelu medycznego, powołanego do przeprowadzenia zasadniczych czynności leczniczych, mogłoby prowadzić do znacznie poważniejszych naruszeń praw pacjentów, aniżeli te, które mają miejsce na gruncie obowiązujących przepisów ${ }^{32}$.

W przypadku, kiedy małoletni pacjent ukończył 16 rok życia, ale jest niezdolny do świadomego wyrażenia zgody, o udzieleniu mu świadczenia zdrowotnego samodzielnie rozstrzyga przedstawiciel ustawowy (art. 32 ust. 2 i art. 34 ust. 3 u.z.1.). W razie niezdolności małoletniego pacjenta, który ukończył 16 rok życia, do świadomego wyrażenia zgody następuje modyfikacja podmiotowej struktury zgody, w wyniku czego do legalnego udzielenia świadczenia zdrowotnego konieczne jest uzyskanie nie zgody podwójnej, lecz wyłącznie zgody przedstawiciela ustawowego jako podmiotu w takiej sytuacji wyłącznie uprawnionego do podejmowania decyzji medycznych dotyczących małoletniego pacjenta ${ }^{33}$.

Jeżeli zachodzi potrzeba przeprowadzenia badania małoletniego, w przypadku braku przedstawiciela ustawowego, zgodę na jego wykonanie może wyrazić także opiekun faktyczny (art. 32 ust. 3 i art. 33 ust. 1 u.z.l. w zw. z art. 17 ust. 2 zd. 2 u.pr.pac.). Należy jednak podkreślić, że prawodawca nie przyznaje opiekunowi faktycznemu takich uprawnień jak przedstawicielowi ustawowemu. Zgoda opiekuna faktycznego jest potrzebna jedynie do przeprowadzenia standardowych badań lub udzielenia świadczenia zdrowotnego o zwykłym ryzyku, gdy pacjent nie wymaga niezwłocznej pomocy lekarskiej.

Jeżeli małoletni, który ukończył 16 lat, sprzeciwia się czynnościom leczniczym, poza zgodą jego przedstawiciela ustawowego lub opiekuna faktycznego albo w przypadku niewyrażenia przez nich zgody, wymagane jest zezwolenie sądu opiekuńczego (art. 32 ust. 6 w zw. z art. 34 ust. 5 u.z.l. w zw. $\mathrm{z}$ art. 17 ust. 3 u.pr.pac.). Prawo do wyrażenia sprzeciwu przysługuje wszyst-

\footnotetext{
${ }^{32}$ Wyrok Trybunału Konstytucyjnego z dnia 11 października 2011 r., K 16/10, LEX nr 992832.

${ }^{33}$ B. JANISZEWSKA, Zgoda na udzielenie świadczenia zdrowotnego, s. 540.
} 
kim małoletnim pacjentom, którzy ukończyli 16 lat, bez względu na stan ich świadomości, czyli także ubezwłasnowolnionym, chorym psychicznie albo upośledzonym umysłowo. Sprzeciw może być wyrażony werbalnie albo niewerbalnie przez takie zachowanie małoletniego pacjenta, które w sposób niebudzący wątpliwości wskazuje na brak woli poddania się czynnościom leczniczym. Wyrażenie sprzeciwu oznacza, że małoletni pacjent posiada dostateczne rozeznanie swej sytuacji zdrowotnej oraz konsekwencji swojego stanowiska. W przypadku wyrażenia przez małoletniego pacjenta sprzeciwu odnośnie do udzielenia mu świadczenia zdrowotnego konieczne jest uzyskanie zezwolenia sądu opiekuńczego, nawet jeżeli przedstawiciel ustawowy lub opiekun faktyczny małoletniego pacjenta wyraził zgodę na wykonanie danej czynności leczniczej. Przepis art. 32 ust. 6 u.z.l. przewiduje kompetencje sądu opiekuńczego do udzielenia zezwolenia w przypadku konfrontacji woli pacjenta małoletniego, który ukończył 16 lat i który sprzeciwił się czynnościom leczniczym oraz woli przedstawiciela ustawowego albo opiekuna faktycznego (w zakresie badania diagnostycznego) wyrażającego zgodę na interwencję medyczną względem małoletniego albo w przypadku podwójnego sprzeciwu - małoletniego pacjenta, który ukończył 16 lat, oraz jego przedstawiciela ustawowego albo opiekuna faktycznego, natomiast nie przewiduje sytuacji, w której małoletni pacjent nie sprzeciwia się interwencji medycznej, a nie zgadza się na nią przedstawiciel ustawowy lub opiekun faktyczny. Należy zgodzić się ze stanowiskiem, że w takiej sytuacji uzasadniona jest ingerencja sądu opiekuńczego w myśl wnioskowania a maiori ad minus ${ }^{34}$.

W przypadku, kiedy przedstawiciel ustawowy małoletniego pacjenta nie zgadza się na wykonanie przez lekarza zabiegu operacyjnego albo stosowania metody leczenia lub diagnostyki stwarzającej podwyższone ryzyko, a niezbędnych dla usunięcia niebezpieczeństwa utraty życia lub ciężkiego uszkodzenia ciała bądź ciężkiego rozstroju zdrowia, lekarz może wykonać takie czynności po uzyskaniu zgody sądu opiekuńczego (art. 34 ust. 6 u.z.l.). Należy dodać, że przyczyną odmowy wyrażenia zgody na udzielenie świadczenia zdrowotnego może być wszystko: względy religijne, przekonania światopoglądowe, brak zaufania do lekarzy, chęć skrócenia cierpień śmiertelnie chorego dziecka. O wykonanych czynnościach lekarz niezwłocznie zawiadamia przedstawiciela ustawowego, opiekuna faktycznego lub sąd opiekuńczy.

\footnotetext{
${ }^{34}$ T. DuKIEt-NAgÓRSKA, Świadoma zgoda pacjenta $w$ ustawodawstwie polskim, „Prawo i Medycyna" 2000, nr 6-7, s. 92.
} 


\section{ZEZWOLENIE SĄDU NA UDZIELENIE MALOLETNIEMU PACJENTOWI ŚWIADCZENIA ZDROWOTNEGO}

W przypadkach niewyrażenia zgody na udzielenie świadczenia zdrowotnego przez podmioty uprawnione albo kiedy brak jest podmiotów uprawnionych do wyrażenia zgody o udzieleniu bądź odstąpieniu od udzielenia świadczenia zdrowotnego rozstrzyga sąd opiekuńczy. Należy podkreślić, że jego rolą nie jest substytuowanie przedstawiciela ustawowego, a jedynie stworzenie samodzielnej podstawy legalnego podjęcia czynności leczniczych (art. 32 ust. 1 u.z.l.). Tym samym sąd opiekuńczy staje się dysponentem zgody medycznej. Sąd opiekuńczy rozstrzyga o udzieleniu małoletniemu pacjentowi świadczenia zdrowotnego, kierując się wyłącznie dobrem dziecka. W ten sposób samodzielnie realizuje funkcję opiekuńczą względem dziecka. Stanowisko sądu ma charakter zupełny, jest w pełni samodzielne, nie zastępuje oświadczenia podmiotu, którego złożenie albo niemożność złożenia stały się przyczyną zainicjowania postępowania o wydanie zezwolenia na udzielenie małoletniemu pacjentowi świadczenia zdrowotnego.

Rozstrzygnięcie sądu opiekuńczego w postaci zezwolenia na udzielenie świadczenia zdrowotnego powinno być sformułowane w sposób konkretny, możliwie szczegółowy, powinno dokładnie określać zakres zezwolenia i rodzaj świadczenia zdrowotnego. Nie może pozostawiać lekarzowi nieograniczonej swobody działania, takie zezwolenie jest sprzeczne z prawem. Oczywiście zawarcie w treści zezwolenia sądu opiekuńczego wszystkich elementów planowanego leczenia może okazać się niemożliwe. Nie oznacza to jednak, że sąd opiekuńczy może udzielać zezwolenia w sposób blankietowy. Zezwolenie na udzielenie świadczenia zdrowotnego musi być określone w taki sposób, by wszelkie składowe i konsekwencje planowanego leczenia były możliwe do określenia na podstawie aktualnej wiedzy medycznej i przyjmowanych standardowych procedur. Zezwolenie sądu opiekuńczego staje się dla lekarza wyznacznikiem zgodnego $\mathrm{z}$ prawem zachowania względem małoletniego pacjenta. Stwarza bowiem jednoznaczną podstawę do podjęcia albo zaniechania interwencji medycznej ${ }^{35}$. Po wyrażeniu zezwolenia przez sąd opiekuńczy lekarz może udzielić świadczenia zdrowotnego bez względu na stanowisko rodziców małoletniego pacjenta. Przyjęte regulacje stabilizują sytuację prawną i zapewniają bezpieczeństwo prawne zarówno oczekujących na interwencję medyczną małoletnich pacjentów, jak i personelu medycznego.

${ }^{35}$ B. JANISZEWSKA, Zgoda na udzielenie świadczenia zdrowotnego, s. 566 
Wiadomo bowiem kto i czego może się spodziewać i wymagać oraz kto i do czego jest uprawniony i zobowiązany.

Zezwolenie sądu opiekuńczego umożliwia udzielenie świadczenia zdrowotnego, ale do tego nie zobowiązuje, jeżeli wskazania medyczne od czasu jego wydania do momentu realizacji uległy zmianie. $Z$ reguły stan zdrowia pacjenta wymagającego interwencji medycznej zmienia się czasami bardzo dynamicznie. W konsekwencji nierzadko celowe jest wykonanie czynności innej niż ta, na którą zezwolił sąd opiekuńczy, nawet bez konieczności oczekiwania na jego zezwolenie.

Na marginesie należy dodać, że odmienne uregulowania dotyczące wieku małoletniego pacjenta uprawnionego do wyrażenia zgody na interwencję medyczną wynikają przede wszystkim z: art. 4a ust. 4 ustawy z dnia 7 stycznia 1993 r. o planowaniu rodziny, ochronie płodu ludzkiego i warunkach dopuszczalności przerywania ciąży ${ }^{36}$, który uzależnia przerwanie ciąży u małoletniej powyżej 13 roku życia od jej pisemnej zgody (oprócz zgody przedstawiciela ustawowego), a małoletniej poniżej 13 roku życia przyznaje prawo wyrażenia własnej opinii wobec sądu opiekuńczego wyrażającego zgodę na wykonanie zabiegu przerwania ciąży; art. 12 ust. 3 ustawy z dnia 1 lipca 2005 r. o pobieraniu, przechowywaniu i przeszczepianiu komórek, tkanek i narządów ${ }^{37}$, który (poza zgodą przedstawiciela ustawowego) wymaga zgody małoletniego powyżej 13 roku życia na pobranie od niego szpiku kostnego lub komórek krwiotwórczych krwi obwodowej; art. 15 ust. 2 ustawy z dnia 22 sierpnia 1997 r. o publicznej służbie krwi ${ }^{38}$, zgodnie z treścią którego, jeżeli przemawiają za tym względy fizjologiczne lub lecznicze, kandydatem na dawcę krwi lub dawcą krwi może zostać osoba nieposiadająca pełnej zdolności do czynności prawnych, powyżej 17 roku życia, po wyrażeniu przez nią oraz przez jej przedstawiciela ustawowego, w obecności lekarza, w formie pisemnej, zgody na pobranie krwi; art. 25 ust. 2 u.z.l., który dopuszcza udział małoletniego w eksperymencie medycznym pod warunkiem jego pisemnej zgody (oprócz zgody przedstawiciela ustawowego), jeżeli małoletni ukończył 16 lat bądź nie ukończył 16 lat, lecz jest w stanie z rozeznaniem wypowiedzieć opinię w sprawie swego uczestnictwa w takim eksperymen-

\footnotetext{
${ }^{36}$ Ustawa z dnia 7 stycznia 1993 r. o planowaniu rodziny, ochronie płodu ludzkiego i warunkach dopuszczalności przerywania ciąży, Dz. U. 1993, nr 17, poz. 78 z późn. zm.

${ }^{37}$ Ustawa z dnia 1 lipca 2005 r. o pobieraniu, przechowywaniu i przeszczepianiu komórek, tkanek i narządów, tekst jedn. Dz. U. 2019, poz. 1405 z późn. zm.

${ }^{38}$ Ustawa z dnia 22 sierpnia 1997 r. o publicznej służbie krwi, tekst jedn. Dz. U. 2019, poz. 1122 z późn. zm.
} 
cie; art. 306 KPC, który przewiduje możliwość pobrania krwi w celach dowodowych wyłącznie za zgodą osoby, której krew ma być pobrana, a jeżeli osoba ta nie ukończyła 13 roku życia - za zgodą przedstawiciela ustawowego. Z uwagi na specyfikę każdego z tych przypadków, uzasadniającą odrębnego uregulowania zasad wykonywania tych czynności, problematyka ta została pominięta.

Postępowanie w sprawie udzielenia zezwolenia wszczynane jest z urzędu, wskutek zawiadomienia o zaistnieniu okoliczności uzasadniających rozstrzygnięcie o konieczności podjęcia interwencji medycznej. Sądem opiekuńczym właściwym miejscowo dla udzielenia zgody na wykonanie czynności leczniczych jest sąd, w którego okręgu czynności te mają być wykonane (art. 32 ust. 10 u.z.1.). Jednakże $w$ stanach nagłych sąd opiekuńczy wydaje $\mathrm{z}$ urzędu wszelkie potrzebne zarządzenia nawet w stosunku do osób, które nie podlegają jego właściwości miejscowej, zawiadamiając o tym sąd opiekuńczy miejscowo właściwy (art. $569 \S 2$ KPC).

\section{UDZIELENIE MAŁOLETNIEMU ŚWIADCZENIA ZDROWOTNEGO BEZ UZYSKANIA ZGODY PODMIOTÓW UPRAWNIONYCH}

W stanach nagłych, kiedy pacjent wymaga niezwłocznej pomocy lekarskiej, a ze względu na stan zdrowia lub wiek nie może wyrazić zgody i nie ma możliwości porozumienia się z jego przedstawicielem ustawowym lub opiekunem faktycznym, dopuszczalne jest przeprowadzenie badania lub udzielenie innego świadczenia zdrowotnego bez jego zgody. W takim przypadku decyzję o podjęciu interwencji medycznej lekarz powinien w miarę możliwości skonsultować z innym lekarzem. Okoliczności te odnotowuje w dokumentacji medycznej pacjenta (art. 33 u.z.1.). Podstawą takiej decyzji lekarza jest analiza sytuacji zdrowotnej pacjenta, dokonana z perspektywy uwarunkowań diagnostycznych, terapeutycznych i prognostycznych. Decydując się na podjęcie interwencji medycznej bez zgody pacjenta, lekarz musi kierować się wyłącznie jego dobrem. Należy dodać, że interwencja medyczna w stanach nagłych powinna ograniczać się wyłącznie do czynności niezbędnych, czyli takich, których podjęcie jest konieczne, by zażegnać niebezpieczeństwo dla życia lub zdrowia małoletniego pacjenta.

Przekroczenie granic zgody pacjenta może nastąpić także w przypadku konieczności przeprowadzenia badania lub udzielenia innych świadczeń zdrowotnych, a także wykonania zabiegu operacyjnego albo zastosowania metody leczenia lub diagnostyki stwarzającej podwyższone ryzyko dla pa- 
cjenta, gdy zwłoka spowodowana postępowaniem w sprawie uzyskania zgody groziłaby pacjentowi niebezpieczeństwem utraty życia, ciężkiego uszkodzenia ciała lub ciężkiego rozstroju zdrowia, a nie ma możliwości niezwłocznego uzyskania zgody pacjenta lub jego przedstawiciela ustawowego bądź zgody właściwego sądu opiekuńczego. W takim przypadku lekarz staje się z mocy prawa uprawniony do samodzielnego podjęcia decyzji dotyczącej wykonania interwencji medycznej. Co prawda zobowiązany jest do zasięgnięcia opinii drugiego lekarza, w miarę możliwości tej samej specjalności, jednakże tylko wówczas, kiedy jest to możliwe. O wykonywanych czynnościach lekarz niezwłocznie zawiadamia pacjenta, jego przedstawiciela ustawowego, opiekuna faktycznego lub sąd opiekuńczy, w zależności od sytuacji, w jakiej znajduje się pacjent, stanu zdrowia i wieku, oraz dokonuje odpowiedniej adnotacji wraz z uzasadnieniem podjęcia decyzji o przeprowadzeniu interwencji medycznej w dokumentacji medycznej (art. 32 ust. 9 w zw. z 34 ust. 7-8 u.z.1.).

Z treści przywołanych przepisów, w związku z unormowaniami dotyczącymi powinności zawodowych lekarza wynika, że jest on zobowiązany do wykonywania wszelkich czynności zmierzających do odwrócenia niebezpieczeństwa dla życia lub zdrowia człowieka. Potwierdza to art. 30 u.z.l., który zobowiązuje lekarza do udzielenia pomocy lekarskiej w każdym przypadku, gdy zwłoka w jej udzieleniu mogłaby spowodować niebezpieczeństwo utraty życia, ciężkiego uszkodzenia ciała lub ciężkiego rozstroju zdrowia, oraz w innych przypadkach niecierpiących zwłoki. Należy podkreślić, że postanowienia art. 30 u.z.l. dotyczą wyłącznie sytuacji niespodziewanych. Ocena tego, czy w danym przypadku zaistniały wskazane okoliczności, pozostawiona jest uznaniu lekarza. Rozwiązanie to $z$ jednej strony usuwa niebezpieczeństwo pozostawienia pacjenta, który znajdzie się w takich okolicznościach, bez pomocy, z drugiej natomiast, pozostawia uznaniu lekarza podjęcie decyzji o udzieleniu świadczenia zdrowotnego z pominięciem konieczności uzyskania zgody podmiotów uprawnionych do jej wyrażenia bądź uzyskania zezwolenia sądu opiekuńczego.

W analizowanych unormowaniach art. 32 i 34 u.z.l. prawodawca określa interwencję sądu opiekuńczego w sposób niejednolity. W art. 32 ust. 2 i 6 oraz art. 34 ust. 3 u.z.l. mowa jest o ,zezwoleniu sądu opiekuńczego”. Podobnie ocenić należy art. 34 ust. 5 u.z.l., który odsyła do posługującego się tym pojęciem art. 32 ust. 6 u.z.l. Natomiast w art. 32 ust. 8 u.z.l. oraz art. 34 ust. 6 u.z.l. posłużono się pojęciem „zgoda sądu opiekuńczego”. Niewątpliwie odwołanie się w treści przepisów do różnych pojęć ma znaczenie dla interpretacji tekstu prawnego. Zasady prawidłowej wykładni językowej oraz założenie racjonal- 
ności prawodawcy nakazywałyby przydać wskazanemu rozróżnieniu znaczenie prawne. Jednakże analiza skutków prawnych orzeczenia sądu wyrażonego bądź to w formie ,zezwolenia”, bądź „zgody” nie pozwala na uchwycenie różnic między tymi pojęciami. Do podobnych wniosków prowadzi analiza funkcjonalna przywołanych regulacji prawnych. Interwencja sądu opiekuńczego we wszystkich wymienionych przypadkach następuje w razie braku wymaganej prawem zgody pacjenta lub jego przedstawiciela ustawowego albo opiekuna faktycznego (w zakresie badania diagnostycznego). Skutkiem orzeczenia sądu (zezwolenia lub zgody) jest umożliwienie przeprowadzenia legalnej interwencji medycznej. W związku z tym należy przyjąć, że między tymi pojęciami nie zachodzą istotne różnice konstrukcyjne ${ }^{39}$. Niemniej jednak od racjonalnego prawodawcy należałoby oczekiwać konstruowania przepisów prawnych w sposób niebudzący żadnych wątpliwości co do ich treści i znaczenia normatywnego.

\section{WNIOSKI KOŃCOWE}

Podsumowując, należy stwierdzić, że podstawą każdej interwencji medycznej i w konsekwencji udzielania świadczeń zdrowotnych jest „poinformowana zgoda" pacjenta, a w przypadku małoletniego pacjenta jego przedstawiciela ustawowego, opiekuna prawnego, opiekuna faktycznego albo sądu opiekuńczego. W pewnych sytuacjach prawodawca przewiduje konieczność uzyskania zgody podwójnej przedstawiciela ustawowego bądź opiekuna prawnego pacjenta małoletniego i samego zainteresowanego, pod warunkiem, że ukończył on 16 rok życia. Zgoda na udzielanie świadczeń zdrowotnych ma doprowadzić do zapewnienia względnej równowagi między pacjentem a lekarzem jako partnerów tego samego procesu leczniczego i w konsekwencji zapewnić pacjentowi możliwość współdecydowania o jego przebiegu ${ }^{40}$. Lekarz nie może decydować za pacjenta, co będzie dla niego korzystne. Pomimo oczywistych zalet wynikających z zaangażowania sądu opiekuńczego w podejmowanie decyzji o udzielaniu zezwolenia / zgody na interwencję medyczną względem małoletniego pacjenta należy podkreślić, że przyznana kompetencja stanowi ingerencję zarówno w autonomię decyzyjną takiego

${ }^{39}$ J. SŁYK, Zezwolenie (zgoda) sądu opiekuńczego na udzielenie świadczenia zdrowotnego małoletniemu pacjentowi (art. 32 i 34 ustawy o zawodach lekarza i lekarza dentysty), „Prawo w działaniu. Sprawy cywilne" 2016, nr 25, s. 155

${ }^{40} \mathrm{~W}$. Lis, Zgoda pacjenta na czynność medyczna, s. 40 
pacjenta bądź jego przedstawicieli ustawowych, jak również w wykonywanie przez nich pieczy nad osobą dziecka. Oznacza to, że zakres władzy rodzicielskiej podlega stałemu nadzorowi ze strony sądu opiekuńczego, który może orzec wbrew woli przedstawicieli ustawowych małoletniego.

$\mathrm{Na}$ zasadzie wyjątku, w sytuacjach szczególnego zagrożenia życia lub zdrowia człowieka, świadczenia zdrowotne udzielane są na podstawie decyzji lekarza. W takich bowiem przypadkach jakakolwiek zwłoka w udzieleniu świadczenia zdrowotnego mogłaby się wiązać z zaistnieniem negatywnych dla człowieka skutków zdrowotnych. Interwencja sądu jest możliwa i konieczna wówczas, kiedy: 1) nie jest możliwe uzyskanie zgody małoletniego pacjenta, jego przedstawiciela ustawowego, opiekuna prawnego albo opiekuna faktycznego (w zakresie badania diagnostycznego), 2) oświadczenia tych podmiotów są ze sobą sprzeczne, 3) przedstawiciel ustawowy, opiekun prawny albo opiekun faktyczny (w zakresie badania diagnostycznego) małoletniego pacjenta nie zgodził się na dokonanie czynności leczniczej, niezbędnej do usunięcia niebezpieczeństwa dla jego życia lub zdrowia, przy braku sprzeciwu małoletniego pacjenta, 4) małoletni pacjent sprzeciwił się udzieleniu świadczenia zdrowotnego. W kontekście konieczności uzyskania zezwolenia sądu opiekuńczego na udzielenie świadczenia zdrowotnego należy zwrócić uwagę na niebezpieczeństwo wkraczania sądu opiekuńczego w rolę przedstawiciela ustawowego bądź opiekuna prawnego w przypadku, kiedy nie została spełniona przesłanka braku przedstawiciela ustawowego lub opiekuna prawnego bądź niemożności porozumienia się z nimi, ponieważ ci są i faktycznie istnieje możliwość porozumienia z nimi. Na skutek interwencji sądu opiekuńczego przedstawiciel ustawowy bądź opiekun prawny zostają pozbawieni wpływu na podejmowanie decyzji o sytuacji zdrowotnej małoletniego pacjenta w okolicznościach konkretnego przypadku, co może mieć daleko idące konsekwencje faktyczne i prawne.

Rozstrzygnięcia sądu opiekuńczego, ze względu na charakter spraw, których przedmiotem jest ochrona życia i zdrowia ludzkiego, powinny być wydawane w jak najkrótszym czasie. Nierzadko powoduje to rezygnację z postępowania dowodowego bądź ograniczenia go do minimum. W konsekwencji rozstrzygnięcia opierają się wyłącznie na stanowisku lekarza. Niewątpliwie wynika to ze specyfiki postępowań w sprawie wydania zezwolenia na udzielenie świadczenia zdrowotnego, determinowanego kryterium czasu, jednakże działanie takie może prowadzić do podważenia potrzeby istnienia wymogu uzyskiwania zezwoleń sądu opiekuńczego na udzielenie świadczenia zdrowotnego na rzecz decyzji lekarza samodzielnie rozstrzygającego o podjęciu interwencji medycznej. Wyłączną podstawą rozstrzygnięcia sądu 
opiekuńczego staje się wówczas informacja przekazana przez lekarza. Ograniczenie się do informacji przekazywanych przez lekarza występującego do sądu opiekuńczego o udzielenie zezwolenia stawia ów sąd w roli podmiotu akceptującego stanowisko lekarza i powoduje, że zezwolenie takie ma charakter formalny. Sprawowany w taki sposób nadzór nad działalnością leczniczą jest nieefektywny i jako taki nie służy merytorycznemu rozstrzyganiu o potrzebie udzielenia świadczenia zdrowotnego. Tymczasem jednym z podstawowych zadań sądu opiekuńczego jest nadzorowanie decyzji dotyczących zdrowia małoletniego w sytuacji zaburzeń w wykonywaniu swoich obowiązków przez osoby, pod władzą których pozostaje. W kontekście informacji stanowiących podstawę zezwolenia sądu opiekuńczego na udzielenie świadczenia zdrowotnego należałoby oczekiwać większej rozwagi i samodzielności w ocenie okoliczności uzasadniających jego wydanie. Kryterium czasu stanowi podstawowy czynnik decydujący o efektywności interwencji medycznej. Szybkość postępowania odpowiada specyfice spraw, które muszą być załatwione jak najszybciej z uwagi na dobro pacjenta. Niemniej jednak uniemożliwia to fachową weryfikację celowości udzielenia świadczeń zdrowotnych. W konsekwencji zezwolenie sądu służy nie tyle merytorycznej kontroli proponowanej czynności leczniczej, ile raczej usunięciu przeszkody formalnej (np. braku zgody przedstawiciela ustawowego) w jej przeprowadzeniu. Zapewne także czynnikiem decydującym o wysokim odsetku spraw kierowanych do sądów opiekuńczych jest niechęć lekarzy do działania samodzielnie $^{41}$. Przyjęte rozwiązanie stanowi błędne koło, uwalnia bowiem lekarzy od obowiązku samodzielnego decydowania o udzieleniu świadczenia zdrowotnego i przerzuca go na sąd opiekuńczy, który z kolei zezwolenie na udzielenie świadczenia zdrowotnego wydaje na podstawie informacji przekazywanych przez lekarza. W konsekwencji nadzór sądów opiekuńczych nad świadczeniami zdrowotnymi udzielanymi bez zgody pacjenta albo podmiotów uprawionych do decydowania w jego zastępstwie staje się iluzją.

\section{BIBLIOGRAFIA}

\section{AKTY NORMATYWNE}

Konstytucja Rzeczypospolitej Polskiej z dnia 2 kwietnia 1997 r., Dz. U. 1997, nr 78, poz. 483 z późn. zm.

Ustawa z dnia 25 lutego 1964 r. Kodeks rodzinny i opiekuńczy, tekst jedn. Dz. U. 2019, nr 2086. Ustawa z dnia 3 kwietnia 1964 r. Kodeks cywilny, tekst jedn. Dz. U. 2019, poz. 1145 z późn. zm.

${ }^{41}$ J. SŁYK, Zezwolenie (zgoda) sq̨du opiekuńczego, s. 177-178 
Ustawa z dnia 17 listopada 1964 r. Kodeks postępowania cywilnego, tekst jedn. Dz. U. 2019, poz. $1460 \mathrm{z}$ późn. zm.

Ustawa z dnia 7 stycznia 1993 r. o planowaniu rodziny, ochronie płodu ludzkiego i warunkach dopuszczalności przerywania ciąży, Dz. U. 1993, nr 17, poz. 78 z późn. zm.

Ustawa z dnia 5 grudnia 1996 r. o zawodach lekarza i lekarza dentysty, tekst jedn. Dz. U. 2019, poz. 537 z późn. zm.

Ustawa z dnia 6 czerwca 1997 r. Kodeks karny, tekst jedn. Dz. U. 2019, poz. 1950 z późn. zm.

Ustawa z dnia 22 sierpnia 1997 r. o publicznej służbie krwi, tekst jedn. Dz. U. 2019, poz. 1122 z późn. zm.

Ustawa z dnia 1 lipca 2005 r. o pobieraniu, przechowywaniu i przeszczepianiu komórek, tkanek i narządów, tekst jedn. Dz. U. 2019, poz. 1405 z późn. zm.

Ustawa z dnia 6 listopada 2008 r. o prawach pacjenta i Rzeczniku Praw Pacjenta, tekst jedn. Dz. U. 2019, poz. 1127 z późn. zm.

Ustawa z dnia 15 kwietnia 2011 r. o działalności leczniczej, tekst jedn. Dz. U. 2018, poz. 2190 z późn. zm.

\section{ORZECZNICTWO}

Wyrok Trybunału Konstytucyjnego z dnia 11 października 2011 r., K 16/10, LEX nr 992832.

Wyrok Sądu Najwyższego z dnia 17 grudnia 2004 r., II CK 303/04, LEX nr 157493.

Wyrok Sądu Najwyższego z dnia 11 kwietnia 2006 r., II CSK 191/05, LEX nr 274261.

Wyrok Sądu Najwyższego z dnia 16 maja 2012 r., III CSK 227/11, LEX nr 1211885.

Postanowienie Sądu Najwyższego z dnia 3 czerwca 2011 r., III CSK 259/10, LEX nr 1129120.

Postanowienie Sądu Najwyższego z dnia 10 kwietnia 2015 r., III KK 14/15, LEX nr 1712821.

Wyrok Sądu Apelacyjnego w Poznaniu z dnia 29 września 2005 r., I ACa 236/05, LEX nr 175206.

Wyrok Sądu Apelacyjnego w Szczecinie z dnia 2 sierpnia 2012 r., I ACa 443/12, LEX nr 1237851.

Wyrok Sądu Apelacyjnego w Warszawie z dnia 5 lutego 2016 r., I ACa 609/15, LEX nr 2050471.

\section{LITERATURA PRZEDMIOTU}

CABAN Łukasz, URBAŃSKA Monika: Komentarz do art. 34, punkt 1, [w:] Ustawa o zawodach lekarza i lekarza dentysty. Komentarz, red. Marcin Kopeć, Warszawa: Wolters Kluwer 2016.

DROZDOwSKA Urszula, WoJTAL Wojciech: Zgoda i informowanie pacjenta, Warszawa: Esculap 2010.

DUKIET-NAGÓRSKA Teresa: Świadoma zgoda pacjenta w ustawodawstwie polskim, „Prawo i Medycyna" 2000, nr 6-7, s. 78-96.

HAAK Henryk: Komentarz do art. 94, punkt 1, [w:] Pokrewieństwo i powinowactwo (pochodzenie dziecka, stosunki między rodzicami a dziećmi, przysposobienie). Komentarz do art. 617-127 KRO oraz związanych z nimi regulacji K.P.C. (art. 453-458, 579-589), Henryk Haak, Anna Haak-Trzuskawska, Warszawa: C.H. Beck 2019.

JANISZEWSKA Beata: Zgoda na udzielenie świadczenia zdrowotnego. Ujęcie wewnątrzsystemowe, Warszawa: C.H. Beck 2013.

LIS Wojciech: Błędy związane z wyrażaniem zgody na udzielenie świadczenia zdrowotnego, „Zeszyty Naukowe KUL” 2018, nr 4, s. 393-403. 
LIS Wojciech: Zgoda pacjenta na czynność medyczną w polskim porządku prawnym, „Zeszyty Naukowe KUL” 2018, nr 3, s. 39-58.

MichaŁowsKa Kinga: Charakter prawny i znaczenie zgody pacjenta na zabieg medyczny, Warszawa: Difin S.A. 2014.

NeSTERowicz Mirosław: Glosa do wyroku Sądu Apelacyjnego w Warszawie z dnia 11 marca 2008 r., I ACa 846/07, „Przegląd Sądowy” 2009, nr 11-12, s. 220-225.

SADOWSKA Monika: Zapobieganie błędom medycznym w praktyce, Warszawa: Wolters Kluwer 2019.

SŁYK Jerzy: Zezwolenie (zgoda) sądu opiekuńczego na udzielenie świadczenia zdrowotnego małoletniemu pacjentowi (art. 32 i 34 ustawy o zawodach lekarza i lekarza dentysty), „Prawo w działaniu. Sprawy cywilne” 2016, nr 25, s. 149-190.

STOJANOWSKA Wanda: Rozstrzyganie przez sąd na podstawie art. 24 i 97 § 2 K.R.O o istotnych sprawach rodziny w braku porozumienia między małżonkami lub rodzicami, „Nowe Prawo” 1985, $\mathrm{nr}$ 7-8, s. 81-92.

\section{ZEZWOLENIE SĄDU OPIEKUŃCZEGO NA UDZIELENIE MAŁOLETNIEMU ŚWIADCZENIA ZDROWOTNEGO}

Warunkiem udzielenia świadczenia zdrowotnego jest zgoda pacjenta. Podstawą jej udzielenia jest rzetelna informacja przekazana przez lekarza w sposób zrozumiały dla odbiorcy. W oparciu na przekazanych informacjach pacjent samodzielnie podejmuje decyzję o skorzystaniu ze świadczenia zdrowotnego albo odmawia skorzystania z takiej możliwości. Nie dotyczy to małoletnich, za których decyzję w tym zakresie podejmują rodzice albo inne podmioty sprawujące nad nim pieczę. W przypadku niewyrażenia zgody na udzielenie świadczenia zdrowotnego, pomimo istnienia wskazań lekarskich albo w przypadku konfliktu stanowisk podmiotów uprawnionych do jej wyrażenia, inicjatywę przejmuje sąd opiekuńczy.

Słowa kluczowe: pacjent małoletni; świadczenie zdrowotne; obowiązek informacyjny; zgoda pacjenta; wyjątek terapeutyczny; zezwolenie sądu

\section{PERMISSION OF A GUARDIANSHIP COURT TO PROVIDING HEALTH SERVICES TO THE JUVENILE}

The condition for the provision of health services is patient's consent. The basis for its granting is reliable information provided by the doctor in a manner understandable to the recipient. Based on the information provided, the patient makes his own decision on the use of the health service or refuses to make use of this possibility. This does not apply to minors for whom the decision is made by parents or other entities exercising custody over him. In the event of disagreement with the provision of health services, despite the existence of medical indications or in the event of a conflict of positions of entities authorized to express it, the initiative is taken over by the guardianship court.

Keywords: juvenile patient; health service; information obligation; patient's consent; therapeutic exception; court permission 